\title{
INTERNATIONAL EXPERIENCE OF CREATION LOGISTIC PARK
}

\author{
Ph.D. student Tleulina Aigerim \\ People's Republic of China, Hunan province, Xiangtan city, Hunan Technical University of science \\ and technology
}

DOI: https://doi.org/10.31435/rsglobal_ijite/31032020/6963

\section{ARTICLE INFO}

Received 27 January 2020

Accepted 18 March 2020

Published 31 March 2020

\section{KEYWORDS}

logistic park, "Belt and

Road", Lianyungang,

China-Kazakhstan logistic

cooperation,

strategic forecast,

free economic zone.

ABSTRACT

One of the main trends of modern economic relations is the transition of priorities from the producer market to the buyer market.

In this regard, the ability to combine production, the planning system with individual purchasing preferences is becoming a decisive factor in competition and the economy of the future. As a result, rapid changes in buyers' preferences, their requests for quality of delivery lead to the need to reduce delivery times and volumes, and to reduce reserve stocks of time and materials. Perhaps the second feature is the strengthening of integration processes among countries, particularly in the context of the expansion of the WTO, with the possibility of placing production in countries with cheaper labor and lower tax rates, and the development of international trade has opened up access to cheaper resources.
\end{abstract}

Citation: Tleulina Aigerim. (2020) International Experience of Creation Logistic Park. International Journal of Innovative Technologies in Economy. 1(28). doi: 10.31435/rsglobal_ijite/31032020/6963

Copyright: (C) 2020 Tleulina Aigerim. This is an open-access article distributed under the terms of the Creative Commons Attribution License (CC BY). The use, distribution or reproduction in other forums is permitted, provided the original author(s) or licensor are credited and that the original publication in this journal is cited, in accordance with accepted academic practice. No use, distribution or reproduction is permitted which does not comply with these terms.

\section{Overview of foreign experience.}

The world system of logistics complexes as a whole has already been formed. The system was pioneered by Atlanta Airport in the United States, where Delta began docking its own flights in the 1950s. Since then, Atlanta has been the busiest airport in the world.

In establishing logistics complexes in the UK, private companies are negotiating with county authorities. When they determine where the centre is to be located, they establish private joint-stock companies. Some logistics centres are established on a partnership basis, with several private companies operating in the same centre. An example of such a project is the city of Milton Keynes (United Kingdom), on whose territory Magna Park is located. The complex includes a huge number of distribution centers offering tenants various logistics operations, including the possibility of several modes of transport. Magna Park is one of the largest projects in the world and a vivid example of the logistics complex.

The geography of Italian logistics complexes and the economic feasibility of their establishment determine the proximity to the intersections of important national and trans-European land routes, shipping routes, airports, as well as production centres, which, when exporting products, make transport infrastructure busy (Milan, Verona, Turin, Trieste, Bologna, Florence, Ancona, etc.).

Logistics centres in Japan have been established in areas where major industries, airports and seaports are located. Such centres, located along international transport corridors, increase the volume of total freight traffic and improve the efficiency of air freight traffic when using these centres as transit airports for refuelling purposes.

In Western Europe, the targeted development of transport logistics centers began in the early 1980 s, owing to the high growth of freight and passenger transport in the context of the globalization of world commodity markets. The construction of large logistics centres (hubs) in Western Europe has become a trend in the past 10-15 years. The area of such projects can exceed 1 million square metres. 
Today, in the world, the initiative and support of the Government is of great importance for the creation of adequate modern technological requirements and market conditions of the logistics complex infrastructure.

For example, the reason for the Dubai hub was the desire of the State to invest and benefit not only from the development of commodity industries, oil and gas production, but also from areas of the economy with higher value added.

The increasing competition between producers has forced them to look for additional opportunities to reduce the transport component in the final price of the goods. As a result, with total world GDP-about 30 trillion dollars. At the beginning of the twenty-first century, the world's direct exports of goods exceeded 6 trillion dollars. Exports of services amounted to $\$ 1.7$ trillion. In turn, the share of components coming from other countries within the framework of international cooperation increased from 19 per cent in the 1980s to 50 per cent in 2005, including 17 / 51 per cent in Germany, 24 / 49 per cent in England, 15 / 40 per cent in Japan, 21 / 48 per cent in France, 14 / 45 per cent in Sweden, 27 / 60 per cent in Holland, 24 / 42 per cent in Belgium. the world.

Consider the foreign experience of the creation of multimodal transport and logistics parks in

In terms of experience in building logistics parks, Germany, Japan and Taiwan are in the forefront of the world. According to their experience and the functions of the logistics park, some international logistics experts divide the logistics park into four categories: according to the completeness of the function, it can be divided into comprehensive logistics park and professional logistics park; according to the logistics service area, it can be divided into international logistics park, national logistics park, regional logistics park and urban logistics park.

According to the service object, it can be divided into logistics park served by production enterprises, logistics park serving commercial retail industry, and social logistics park facing the whole society; from the point of view of specialization, it can be divided into industry logistics park and third-party logistics park.

The construction history of the logistics park in Japan is a little longer, and the earlier construction of the logistics park in Tokyo, Japan, is designed to alleviate the urban traffic pressure.

They have accumulated some experience in the process of building a logistics park, mainly in three aspects: first, attach importance to planning; second, preferential land use and government investment policies; third, good municipal facilities and investment policies.

Germany is a country with relatively perfect transportation development in the world. for them, the current task is to optimize the use of existing transport infrastructure and give full play to their potential.

The German government's approach is to integrate various modes of transport, alleviate the spread of traffic congestion and improve the capacity of the entire transportation system.

Germany generally adopts the development model of overall planning by the federal government, construction supported by the government and municipal government, corporate management, and independent management of resident enterprises.

As a transportation hub, Nuremberg Logistics Park in Germany was built in the mid-1970s and developed into a logistics park in the 1980s, covering an area of 3.37 square kilometers, with a development of 2.17 square kilometers in the first phase and 1.2 square kilometers in the second phase (now under development).

The main body of the construction is the joint-stock company supported by the government, and the capital source of construction governance is mainly from government funding and enterprise loans.

The functions of the joint-stock company in the construction and management of the logistics park are the development of land, public transportation, facilities construction, large-scale equipment leasing, public facilities maintenance, coordination with relevant departments, and so on.

The function of the logistics park is that the resident third-party logistics companies provide international transit logistics, regional logistics and urban distribution services, as well as services for the transportation and processing of renewable resources.

At present, there are more than 30 third-party logistics companies in the park, with an operating volume of 9.1 million tons.

The emergence of logistics parks has greatly promoted the rapid economic development of Japan, Germany and so on. 
According to the research of German authoritative institutions, in the next 10 years, even in countries with highly developed transport industries such as Japan and Germany, the construction of logistics parks is still in a period of vigorous development.

This is based on the fact that after the emergence of the logistics park, it has produced huge economic and social benefits to the enterprises using the park and even to the neighboring cities, which is mainly manifested in: reducing the pressure of logistics on urban traffic, reducing the adverse impact of logistics on the urban environment, improving the economies of scale of logistics management, meeting the requirements of the large-scale development trend of warehouse construction, and meeting the requirements of intermodal transport of goods.

In Germany, the Federal Ministry of Transport, Construction and Urban Affairs has two basic objectives, one of which is "mobility" for transportation. The federal government is committed to increasing investment in integrated transport from the current 62.5 million euros to 115 million euros per year, and will launch strategies to take air pollution, climate change, noise pollution and traffic congestion into account, thus making the economic evaluation of various modes of transport more transparent.

The status of the logistics industry in Germany and even the whole Europe makes the federal government hope to further improve the international image of German logistics.

By improving the working conditions of employees in the freight industry and carrying out basic and in-depth training activities, we can provide sufficient human resources for the development of logistics in Germany.

Three factors affecting logistics park.

In the long run, if enterprises want to choose their own logistics park, they need to consider the following three factors.

1. Have a good plan

When choosing a logistics park, enterprises should first consider whether the relevant national departments have put forward guiding opinions on the construction of international and national logistics parks according to the development of logistics, vehicles and urban layout.

As far as a region is concerned, the core issue of planning is to determine the number, function, scale and location of the park on the basis of correct evaluation, so as to avoid rushing up and seeking perfection in a big way, and to select the main body of the construction of the logistics park. determine the mode of operation.

When the government establishes an enterprise company to operate, it can choose the main body of operation in different ways: rent or sale, or the combination of rent and sale.

2. Attention should be paid to location selection and spatial layout.

When choosing a logistics park, enterprises should consider four major factors in the location choice and spatial layout of the logistics park: first, the park can be connected by at least two modes of transportation, including highway and railway; the second is to select the center of the transportation hub to adapt the layout of the logistics park to the transportation network; third, economic rationality, including lower land price, sufficient quantity and high-quality labor force, etc., to create conditions for park enterprises to obtain necessary benefits; fourth, to meet the requirements of environmental protection and ecological balance.

3. The warehouse of logistics park should be paid attention to.

The warehouse is a scarce commodity, and the land occupied by the logistics park is also a scarce commodity, if the warehouse and land can not be used well. In that case, warehouses will become more and more scarce.

If it is not easy to use because of the unreasonable planning and design of warehouse and logistics park, it will affect the utilization rate, operation efficiency and return on investment of logistics warehouse, and then it will also affect the relationship between supply and demand of logistics warehouse.

In fact, it is not all unsuccessful experiences and lessons, in the logistics park warehouse planning and design, there are still some good logistics park cases.

For example, a large state-owned enterprise in China has developed a set of logistics park warehouse standards in line with China's national conditions in the process of developing logistics park warehouses and logistics centers on a large scale. It is said that this standard has been recognized by foreign well-known logistics real estate developers and used by international logistics research experts for reference.

The development of logistics park is a means to serve the development of economy. 
When an enterprise chooses a logistics park, the first starting point should be to consider its logistics market and the actual and potential logistics demand in the city or region, which is the basis and basis for enterprises to choose logistics park planning.

\section{China-Kazakhstan Logistics Park.}

The China-Kazakhstan logistics terminal in the port of Lianyungang is a vivid example and a model of international logistics cooperation. The logistics cooperation base between China and Kazakhstan (Lianyungang) is the first "Silk Road Economic Belt" physical project put forward and implemented by President Xi Jinping during his visit to Kazakhstan. It is mainly engaged in international cargo transport business such as international multimodal transport, unpacking and consignment, warehousing and so on.

Kazakhstan-Chinese logistics terminal in the port of Lianyungang in northeastern China on the coast of the Yellow Sea has become one of the centers of the resurgent economic belt of the Great Silk Road.

The choice of this port is of great geostrategic importance. Nowadays, it is one of the 25 largest seaports in the world.

Lianyungang occupies an important position between East and West and represents the eastern beginning of a new Eurasian transcontinental corridor.

In the interpretation of strategic significance, Lu Lin pointed out that the construction of the "two bases" of Lianyungang will directly promote the development of the core area of the "Belt and Road Initiative" intersection, and stressed the importance of China-Kazakhstan logistics cooperation base and Shanghai Cooperation Organization Park. When studying the prospect of Sino-Kazakh logistics cooperation, Yang Kailin pointed out that the three parties of the two countries should work together to build an upgraded logistics base. In addition, Lan Shaomin, Wang Congyi, du Junyu and others have followed up and studied the establishment of China-Kazakhstan logistics cooperation base, looking forward to the inestimable node role of China-Kazakhstan logistics. Peng Zhenghuai made it clear in his discussion on the guidance of the China-Kazakhstan (Lianyungang) Logistics Cooperation Base in the "Belt and Road Initiative" strategy that the China-Kazakhstan (Lianyungang) Logistics Cooperation Base is the first physical project in the construction of the "Silk Road Economic Belt". It has important guiding significance for the construction of "Belt and Road Initiative". Only by co-ordinating the overall domestic and international situation and giving full play to the pitting effect of the logistics cooperation base of China and Kazakhstan (Lianyungang), can we help our country to achieve a successful start to the construction work of "Belt and Road Initiative". In expanding strategic advantages, Yang Ruojian pointed out that how to give full play to the radiation role of Lianyungang Logistics Cooperation Base project and promote the development of national key industries has become an important strategic topic.

Shen Kunrong pointed out that Lianyungang should give full play to the role of the eastern node of the Silk Road Economic Belt, serve the new economic policy of "Bright Road" in Kazakhstan, and study the feasibility and operational requirements of policy guarantee cooperation. find a balance between top-level design and base-level vitality;

Liu Kaishan shows in his research that Lianyungang's implementation of the "Belt and Road Initiative" strategy makes Lianyungang occupy the best time and geographical location, but as the eldest brother in the forerunner area of reform and opening up for more than 30 years, its economic development lags behind. as the rear army of coastal economic development, Lianyungang can be "first-to-last" in the regional competition depends on being able to fully grasp the preferential policies given by the state, and it is necessary to pay close attention to the logistics cooperation base between China and Kazakhstan.

In order to expand the strategic advantage, it is helpful for Lianyungang to start later and arrive first, and realize the upturn against the wind.

In May 2014, the construction of the first joint Kazakh-Chinese terminal with an area of 21 hectares was laid on its territory.

"Belt and Road" initiative has opened up Lianyungang's unique development opportunities and strengthened its links with the outside world. On June 7 2017, the first cross-border freight trains to Almaty and Istanbul departed from the China-Kazakhstan logistics terminal of the port of Lianyungang. This demonstrated the successful integration with the logistics terminal of a large deepsea port, a maritime highway and a China-Europe rail route. It is also a new model of logistics cooperation between China and Kazakhstan.

Having become the first "material platform" during the construction of the "Belt and Road", the China-Kazakhstan logistics terminal has earned as an international economic platform of crossborder transport and warehousing logistics of five Central Asian countries. Cross-border freight trains 
departing from the terminal operate at more than 200 railway points in five Central Asian countries, including Istanbul (Turkey) and Duisburg (Germany). Over the past six years Lianyungang has been actively promoting the construction of roads, ports, highways and parks, as well as transport hubs, within the framework of the "Belt and Road".

At present, more than 10 container trains travel regularly to Central Asia and Europe.

They provide more than 30 per cent of China's exports on the New Eurasian Continental Bridge and more than 60 per cent of cross-border traffic to Central Asia. At the same time, more than 40 sea container lines and 13 sea lines have been opened for cargoes without containers.

Sino-Kazakh logistics cooperation is in the development stage of both opportunities and challenges, and the current opportunities are: under the background of excellent international trade development and preferential national policies, China is bound to usher in the golden period of international trade in the next few years.

In order to grasp the golden period of international trade, we should focus on the growth of trade demand, and the China-Kazakhstan logistics cooperation base should respond positively and give full play to its strategic opportunity as the first physical platform of "Belt and Road Initiative".

Therefore, on the basis of ensuring the steady growth of material flow in China-Kazakhstan Logistics Park, we should reasonably forecast logistics demand and prepare ahead of time for the growth of international trade.

The purpose of logistics demand analysis, on the one hand, is to clarify the current transport strength of the logistics park, and the other is to provide data support for the subsequent expansion and transformation of the park.

As an intuitive digital index, the logistics flow of a logistics park can measure the infrastructure level, customer scale group and freight handling capacity of a park.

The demand forecast of the operation material flow of the logistics park can help the park to recognize the future customer demand, and formulate a reasonable park development plan by comparing the material flow in and out of the existing park.

Therefore, exploring the logistics flow of the Sino-Kazakh logistics cooperation base and scientifically forecasting the logistics flow have very important theoretical and practical significance for deepening the planning and construction of the logistics park. Therefore, this section analyzes and forecasts the logistics of the Sino-Kazakh logistics cooperation base.

Since the official operation of China-Kazakhstan Logistics Park in July 2014, logistics flow has been mainly generated by point-to-point transport trains. at present, there are a total of three pointto-point trains. They are Lianyungang-Almaty, Lianyungang-Duisburg and Lianyungang-Tashkent. By the end of 2018, the total volume of goods in and out of the warehouse was 13.2 million tons, and the volume of empty and heavy containers in and out of the warehouse was about 850000 TEU.

The specific data are shown in table 1.

Table 1. Logistics flow Statistics of Kazakhstan Logistics Cooperation Base

\begin{tabular}{|c|c|c|c|}
\hline Year & $\begin{array}{c}\text { Empty and heavy box in and } \\
\text { out of the field/TEU }\end{array}$ & $\begin{array}{c}\text { Disassembly and } \\
\text { packing volume / TEU }\end{array}$ & $\begin{array}{c}\text { Goods in and out of } \\
\text { the warehouse / ton }\end{array}$ \\
\hline $\mathbf{2 0 1 5}$ & 142693 & 31036 & 1423652 \\
\hline $\mathbf{2 0 1 6}$ & 176351 & 28732 & 3214196 \\
\hline $\mathbf{2 0 1 7}$ & 256792 & 17556 & 4242858 \\
\hline $\mathbf{2 0 1 8}$ & 276882 & 14886 & 4321731 \\
\hline
\end{tabular}

As can be seen from table 1 above, the business volume of China-Kazakhstan logistics cooperation base shows an upward trend, with an increase of about $12 \%$ over the same period, and the number of unpacking and packing decreased by $18 \%$ compared with the same period last year.

Due to the large basic data, maintaining a growth rate of more than $10 \%$ all the year round, the facilities of the base can meet the needs of logistics growth in the short term.

In the long run, if the park does not expand or replan the functional area, within a few years, the logistics park will face the crisis of overload operation.

China-Kazakhstan Logistics Cooperation Base Construction Measures

1. Strengthen the construction of software and hardware system of port and logistics

(1) strengthening the construction of port and logistics hardware system, the prerequisite for the smooth implementation of trade between China and Kazakhstan (Lianyungang) logistics 
cooperation base against the port, improving the port logistics hardware system. The Sino-Kazakh logistics cooperation base is a company directly under the port group, and the establishment of the port provides a prerequisite for the import and export trade of the park.

Comprehensively enhance the port and logistics hardware system for foreign trade and ChinaKazakhstan logistics cooperation base train to play a strong supporting capacity, to do this: first, to optimize the functional layout of the port. Revise the port planning, formulate and implement the shoreline utilization plan, complete the regulatory detailed planning of Xuwei Port area and Ganyu Port area, and match the functional facilities for industrial layout and logistics and transportation. The second is to speed up the construction of deep-water waterways.

Upgrade the waterway level and ship berthing capacity, pay more attention to the waterway construction of Lianyungang area, Xuwei Port area, Ganyu Port area and Guanhe Port area, so as to meet the import and export requirements of all kinds of bulk goods. The third is to speed up the construction of specialized wharf berths.

To focus on the construction of an industrial port in Xuwei Port area, and speed up the construction of specialized terminals and industrial supporting terminals such as Sheng Hong Refining and Chemical Integration, Donghua Energy, Satellite Petrochemical and LNG Terminal, so as to meet the needs of international trade going out to sea through Lianyungang and the sustainable development of China-Kazakhstan logistics cooperation base.

(2) to strengthen the construction of port and logistics software system, first of all, it is necessary to clarify the basic function of the port and incorporate the function into the information process.

Ensure timely and effective access to logistics information, focus on the construction of the port logistics information platform, focus on the customs declaration of import and export goods and the schedule of arrival and departure, and strive to achieve one declaration, one inspection and one release.

First of all, strengthen the construction of electronic ports. Led by the Municipal Information Committee entrusted by the Lianyungang Municipal Government, the three major EDI platforms, namely, the customs, the port and the shipping exchange, are effectively integrated, and it is proposed to establish a department specially responsible for electronic ports to achieve local customs declaration, inspection declaration, timely entry of customs declaration and inspection information, and transmit the letter and information to customers at the first time. Second, streamline customs clearance procedures.

Simplify the transit procedures for the import and export of goods as far as possible, especially the import and export of goods from Lianyungang Port, apply for approval in advance, shorten customer waiting time, recommend paperless office system, online declaration, online examination and approval, reduce customer door-to-door processing time, so as to improve the customs clearance efficiency of import and export goods, and then improve customer satisfaction.

2 . Strengthen the construction of logistics system and service capacity.

(1) the development of the industry of constructing "Internet +" efficient logistics system is inseparable from the effective support of the Internet and big data. An efficient logistics system is the preferred factor to win the logistics market. Strengthening the operation level of the Internet of things in the China-Kazakhstan logistics cooperation base and cultivating intelligent logistics enterprises is the development goal of the China-Kazakhstan logistics cooperation base.

Promote the intellectualization of multimodal transport and establish brand trains.

Build the "Information Silk Road", build an international intelligent multimodal transport center oriented to "Belt and Road Initiative", keep abreast of the whole process of multimodal transport, and easily distribute relevant policies, economic and trade market needs and other information of countries and regions along the route. Establish an intelligent distribution system and recognize the importance of intelligent warehousing.

According to the logistics supply and demand information, timely put forward the corresponding distribution route and distribution time; for the containers that need to be stored, query the empty container space in the park, in order to facilitate the principle of entering and leaving, warehousing.

In addition, we will promote the integration and interactive development of intelligent logistics, intelligent transportation, e-commerce and other new forms of industry, so as to form a paperless, networked, intelligent and efficient modern logistics system.

(2) enhance the service consciousness and enhance the added value of logistics.

To realize the comprehensive function of Lianyungang as an open door city of "Belt and Road Initiative", the key is to find the right breakthrough and starting point. At present, most of the goods in 
the hinterland of Lianyungang, especially in the vast area of Longhai-Lanxin Line, do not gather in Lianyungang, but most of them flow to other ports.

Because the hinterland consignors borrow port for export, the short channel is not the only consideration. The collection and distribution conditions of Lianyungang are similar to those of Shanghai, Rizhao, Qingdao, Tianjin and other ports, but they are not as good as them in terms of economic development and functional services, resulting in the loss of customers.

The shortage of hardware should be made up in terms of service software, strengthen internal operation and management, get rid of the mentality of "Hong Kong boss" and "master", uphold the consciousness of "consignor is small owner", lower posture, provide accurate service, reduce charges, improve efficiency, and effectively enhance the function and reputation of port services.

3. Strengthen the logistics service function of the land bridge and play a linkage role.

Lianyungang City is located at the eastern end of the New Eurasian Continental Bridge and has a natural transportation advantage. Make full use of the logistics service function of the land bridge to promote the train to transport products to Asian countries all the way to the west from Lianyungang, along the new continental bridge, so as to increase the density of cooperation with Central Asian countries. In addition, go to sea eastward to increase the density of land and sea intermodal transport in South Korea and Japan, strengthen foreign import and export trade, and provide convenient and affordable logistics and transportation services.

4. Strengthen the cooperation and supporting capacity construction between the logistics park and other parks in Lianyungang.

(1) to improve the functional construction of the park, first of all, to solve the internal problems of the park.

Take the reduction of freight rates as the key goal, consider further solving the problem of high comprehensive freight through policy support, technological innovation and management innovation, in order to gain price advantage in homogenized competition, and attach importance to the introduction of talents. break the age, gender, region, personnel relations and other conditions, select talents rather than academic qualifications and identity, and attract talents from all sides to work in the park. Secondly, highlight the advantageous industries and make great efforts to develop the transportation of agricultural products. Take Kazakh wheat as a breakthrough to attract more agricultural products from the five Central Asian countries to go out to sea in Hong Kong, build a characteristic train of logistics cooperation bases between China and Kazakhstan, and build a demonstration model of "Belt and Road Initiative" agricultural cooperation.

(2) strengthening the ability of cooperation with other parks at present, Lianyungang City has international trade platforms such as the Shanghai Cooperation Organization International Logistics Park, Comprehensive Free Trade Zone and Free Trade Zone, involving a wide variety of goods such as agricultural products, machinery, ores, chemicals, electronic equipment and so on.

5. Strengthen cooperation and resource sharing between China-Kazakhstan logistics cooperation bases and other parks. Strengthen cooperation with the SCO Logistics Park and find more cooperative countries for mutual benefit and common development through the SCO platform.

Start the construction of Sinotrans Shanghai Cooperation Logistics Center as soon as possible, enlarge the east-west two-way opening function of the national eastern, central and western regional cooperation demonstration zone, promote the early use of the comprehensive bonded area, and make good use of Lianyungang Forum, Lianyungang Expo and other open platforms. to create a number of "Belt and Road Initiative" characteristic exhibition brands.

6. Opening up a new international train.

First of all, we will enhance the capacity of cross-border transport routes between Asia and Europe. Speed up the construction of the "two bases" to promote the seamless docking of ports, shipping, roads and parks, and make every effort to build a world-class multimodal transport system.

First, expand and upgrade the infrastructure construction of the China-Kazakhstan base, reduce the cargo turnover time of the China-Kazakhstan logistics transit base by more than half, promote the import and export of containers and goods to a new level, and make every effort to build an international grain logistics transport channel. The second is to improve the carrying capacity of Shanghe Logistics Park.

In order to meet the subsequent entry of a large number of goods into the park, expand the actual operation area of the loading and unloading station and Dazong bulk cargo trading center of the park, and enhance the comprehensive service function of the park. Third, open the China-Europe train 
transport corridor. Deepen cooperation with the Harbin Railway and the Caspian Sea Alliance to keep the Central Asian train in the leading position in the country; smooth the network nodes of the southern line of the European train, and promote the stable operation and regular transportation of the Lianyungang Turkish Istanbul train. Fourth, improve the multimodal transport system.

To speed up the strategy of giving priority to the development of containers, strengthen the construction of Haihe intermodal transport and sea-rail intermodal transport network, and timely increase the number of routes to meet the requirements of goods going to sea. Secondly, under the premise of ensuring the smooth transportation of goods, we should appropriately open up new international trains.

In the new policy "opinions on supporting the Construction and Development of the Shanghai Cooperation Organization (Lianyungang) International Logistics Park and China-Kazakhstan Logistics Cooperation Base" issued not long ago, it is pointed out that in response to the "Belt and Road Initiative" initiative, the provincial government will spare no effort to support the import and export trade of Lianyungang and strive to create the backbone and benchmark of the new Asia-Europe land and sea transport channel.

While ensuring the smooth flow of China-EU train transport routes, we will deepen cooperation with the Harbin Railway and the Caspian Sea Alliance to keep the Central Asian train in a leading position in the country.

7. Opening up international air transport channels.

Speed up the construction of international airports and form an efficient and coordinated transport capacity. There are nine civil aviation airports in Jiangsu, of which the earliest is Nanjing Lukou International Airport (1997), and the latest and most external is Lianyungang Baitabu International Airport (2017). As the shortest express transportation mode among the five major transportation, air transport has priority for international trade, especially for the air transport of special goods. Lianyungang opened the international air train later, which directly affects the transport speed of international air parts.

Therefore, after comprehensively considering the opinions of various parties, the Lianyungang Municipal Party Committee put forward the strategic idea of building an international new airport to the provincial government at a higher level, and successfully approved the project by the State Council and the Central military Commission on January 27, 2018. The new airport (Huaguoshan International Airport) was approved by the State Council and the Central military Commission.

The successful construction of the new airport will make up for the lack of air transport in Lianyungang in international trade, speed up the formation of an integrated transport system of "port, aviation and railway", and form an efficient cooperative transport capacity.

8. Deepen cooperation with Horgos Port and Central Asian countries.

(1) deepen cooperation with Horgos Port Base.

Horgos Port is located in Yili Kazakh Autonomous Prefecture, Xinjiang, China, across the river from Kazakhstan, and has developed into an important port linking Central Asian countries for trade.

More and more "made in China" are transported to the five Central Asian countries and European countries through the Horgos port.

Data show that among the 1668 trains exported through Horgos in 2018, mainly from cities such as Lianyungang and Zhengzhou, the Sino-Kazakh logistics cooperation base in Lianyungang is the region with the largest export volume from Horgos, indicating that the two have close cooperation.

Take Horgostna as the westbound station of China-Kazakhstan logistics cooperation base, declare inbound and outbound freight forwarders here, improve the customs clearance efficiency of China-EU trains, and strengthen cooperation with Horgos port. Publicize the Sino-Kazakh logistics cooperation base as the eastern import and export site, attract orders from Uzbekistan, Kazakhstan, Germany, Poland and other countries to achieve win-win cooperation.

(2) deepen cooperation between China and Kazakhstan logistics cooperation bases and countries. First, deepen cooperation with Central Asian countries.

Central Asia is the key object of cooperation under China's "Belt and Road Initiative" initiative, taking the Sino-Kazakh logistics base as an opportunity for cooperation, and deepening cooperation with Central Asian countries through trade exchanges, with the goal of becoming a model of cooperation in "China-Central Asia" international projects. 
Strategic forecast of Logistics Cooperation between China and Kazakhstan under the background of "Belt and Road " Initiative.

In order to better adapt to the growing market demand under the "Belt and Road Initiative" initiative in the future, avoid the difficulties in the operation of the base caused by excessive material flow in the future, and take precautions against it, a logistics forecasting model is constructed to respond to the sustainable development of the park.

From economy to engineering, prediction is almost a very important factor. There are a lot of software specifically aimed at this field. In this study, the prediction calculation is carried out by Excel.

Prediction program.

The purpose of any prediction is to determine the current trend and to determine the expected results of the subjects at a particular time in the future.

Method 1: Trend line

One of the most popular types of graphical predictions in Excel is to infer by constructing trend lines. Construct a constraint schedule based on tabular data composed of parameters and function values. We need to draw a trend line.

Can choose one of the six types of approximation:

- Linear;

- Logarithm;

- Exponential;

- Linear polynomials;

- Multiplicative power;

- Moving average.

It should be noted that if the prediction time does not exceed $30 \%$ of the base during the analysis period, the prediction inferred from the trend line is valid.

Therefore, over a period of 12 years, we cannot make, effective predictions for more than 3 to 4 years. But even so, unless force majeure occurs during this period and vice versa, it will be relatively credible because it is an extremely favourable environment that did not exist in previous periods.

Method 2 FORECAST operator

The FORECAST feature in Excel allows you to predict future values with some accuracy based on existing values and return the corresponding values.

For example, some objects have properties that change over time.

These changes can be fixed experimentally to produce a table of known $\mathrm{x}$ values and corresponding $\mathrm{y}$ values, where $\mathrm{x}$ is the unit of time and $\mathrm{y}$ represents the quantitative property of the property.

Using the FORECAST function, you can assume the subsequent $\mathrm{y}$ value of the new $\mathrm{x}$ value.

The FORECAST function adopts the linear regression method, and its equation is $y=a x+b$, where:

The coefficients are calculated as $\bar{y}-b \bar{x}(\bar{y}, \bar{x}-$ the smallest arithmetic numbers selected from samples with known $\mathrm{y}$ and $\mathrm{x}$ values are $\mathrm{y}$ and $\mathrm{x}$, respectively).

The coefficient $\mathrm{b}$ is determined according to the following formula:

$$
b=\frac{\sum(x-\bar{x})(y-\bar{y})}{\sum(x-\bar{x})^{2}},
$$

Method 3: TREND operator

You can use another function, TREND, to predict.

It also belongs to the category of statistical operators.

Its syntax is largely similar to that of the FORECAST tool, as follows:

TREND (known value $\mathrm{y}$; known $\mathrm{x}$ value; new marker value $\mathrm{x}$; (tail value).

You can see that the parameters of "known y value" and "known $x$ value" exactly match the same element in the FORECAST statement, while the "new $\mathrm{x}$ value" parameter matches the $\mathrm{X}$ parameter of the previous tool.

In addition, the trend has an additional "consta" argument, but it is not mandatory and will be used only if there are fixed factors. This operator works best when there is a linear constraint on the function.

Method 4: GROWTH operator

Another function of forecasting in EXCELL is the growth operator.

It also applies to a set of tools, but unlike the previous sets, it uses an exponential method rather than a linear constraint. 
The syntax for this tool is as follows:

GROWTH (known value y; known x value; new tag value x; (tail value).

As we have seen, the argument for this function is exactly the same as that of the operator, so we will not repeat these arguments, but will apply them directly to practical applications.

Analysis of forecasting results.

In order to forecast the demand, the logistics flow data of China-Kazakhstan Logistics Park from 2015 to 2018 are selected.

As shown in table 2.

Table 2. Annual material flow of China-Kazakhstan Logistics Cooperation Base

\begin{tabular}{|c|c|c|c|c|}
\hline Year & $\mathbf{2 0 1 5}$ & $\mathbf{2 0 1 6}$ & $\mathbf{2 0 1 7}$ & $\mathbf{2 0 1 8}$ \\
\hline Goods in and out / ton & 1423652 & 1423652 & 4242858 & 4321731 \\
\hline
\end{tabular}

1) Trend line

A) Linear

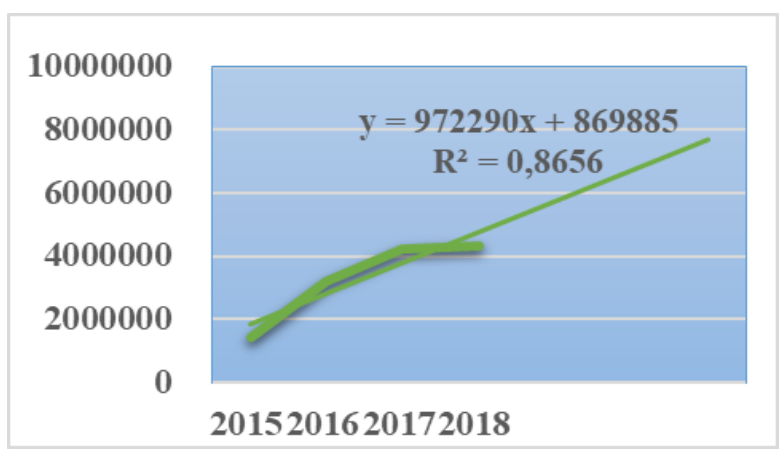

Fig. 1. Linear trend.

After constructing the constraint graph (fig. 1), the linear trend is predicted and calculated by graphic method.

The results of the linear trend are shown in table 3.

Table 3. The result of linear trend

\begin{tabular}{|c|c|c|c|}
\hline Year & $\mathbf{2 0 1 9}$ & $\mathbf{2 0 2 0}$ & $\mathbf{2 0 2 1}$ \\
\hline Goods in and out / ton & 1963923395 & 1964895685 & 1965867975 \\
\hline
\end{tabular}

B) Exponential

The results of the exponential trend are shown in fig. 2 and table 4 .

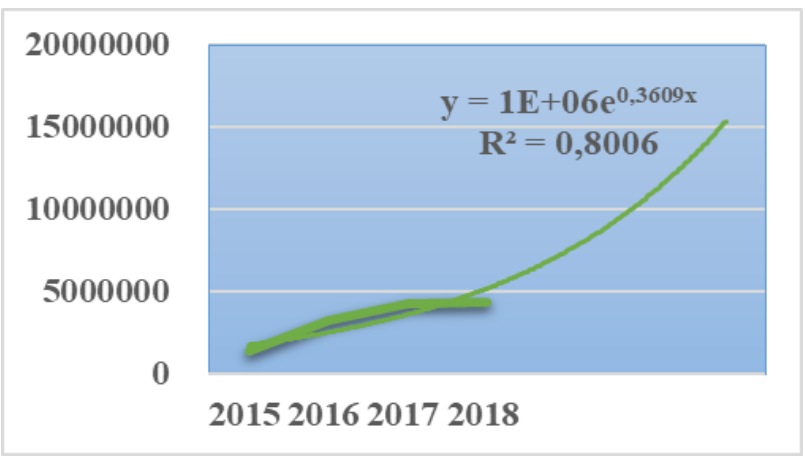

Fig. 2. Exponential trend.

Table 4. The result of exponential trend

\begin{tabular}{|c|c|c|c|}
\hline Year & $\mathbf{2 0 1 9}$ & $\mathbf{2 0 2 0}$ & $\mathbf{2 0 2 1}$ \\
\hline Goods in and out / ton & 6977.12 & 6980.58 & 6984.03 \\
\hline
\end{tabular}

C) Power.

The results of the power trend are shown in fig. 3 and table 5 . 


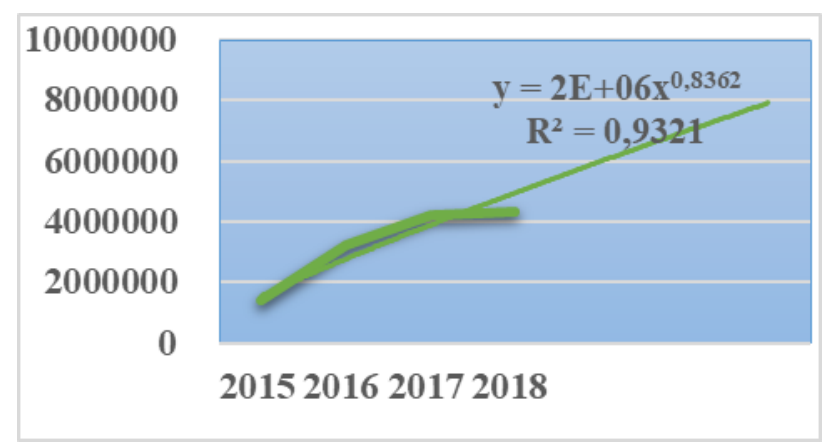

Fig. 3. Power trend.

Table 5. The result of power trend

\begin{tabular}{|c|c|c|c|}
\hline Year & $\mathbf{2 0 1 9}$ & $\mathbf{2 0 2 0}$ & $\mathbf{2 0 2 1}$ \\
\hline Goods in and out / ton & 17378.99 & 17390.31 & 17398.92 \\
\hline
\end{tabular}

2) Use FORECAST, TREND statistical function to analyze and predict.

A) FORECAST.

The material flow is predicted according to the FORECAST function prediction theory, and the results are shown in table 6 .

Table 6. The result of FORECAST function

\begin{tabular}{|c|c|c|c|}
\hline Year & $\mathbf{2 0 1 9}$ & $\mathbf{2 0 2 0}$ & $\mathbf{2 0 2 1}$ \\
\hline Goods in and out / ton & 5731334 & 6285101.5 & 7029339.5 \\
\hline
\end{tabular}

B) TREND.

The material flow is predicted according to the TREND function prediction theory.

The result of the TREND function is exactly the same as that of the FORECAST function, which can be seen in table 7 .

Table 7. The result of TREND function

\begin{tabular}{|c|c|c|c|}
\hline Year & $\mathbf{2 0 1 9}$ & $\mathbf{2 0 2 0}$ & $\mathbf{2 0 2 1}$ \\
\hline Goods in and out / ton & 5731334 & 6285101.5 & 7029339.5 \\
\hline
\end{tabular}

The results are listed in the table 8 .

Table 8. Combination forecasting results

\begin{tabular}{|c|c|c|c|c|c|}
\hline Year & Linear trend & Exponential trend & Power trend & FORECAST & TREND \\
\hline $\mathbf{2 0 1 9}$ & 1963923395 & 6977.12 & 17378.98658 & 5731334 & 5731334 \\
\hline $\mathbf{2 0 2 0}$ & 1964895685 & 6980.58 & 17390.31258 & 6285101.5 & 6285101.5 \\
\hline $\mathbf{2 0 2 1}$ & 1965867975 & 6984.03 & 17398.9203 & 7029339.5 & 7029339.5 \\
\hline
\end{tabular}

Because the result of the graphic method is not accurate, the graphic calculation will have to be abandoned, and the most reliable result is the result of using FORECAST function and TREND function.

Through the forecast of the logistics flow in the park, the results show that the logistics flow of the logistics cooperation base between China and Kazakhstan will keep a steady upward trend in the next few years.

But it is necessary to note that China-Kazakhstan logistics cooperation base is facing a variety of opportunities and challenges. It is not only facing the threat of fierce competition and backward transportation system, but also ushering in a golden development period of strengthening international cooperation and increasing trade volume.

In order to better meet the important historical opportunity of the rapid development of international trade, it is predicted that the logistics flow that may be reached by the China-Kazakhstan logistics cooperation base in the next three years will play a data early warning role for the follow-up development of the park.

The forecast results show that if the park is not expanded, only relying on the existing logistics stations and container yards, the park will face difficulties in cargo handling and transport overload in less than three years. 
In this regard, it is an inevitable trend to deepen the construction of logistics cooperation bases between China and Kazakhstan.

Conclusions. Thus, as the world experience shows, the creation of a national logistics organization with all the characteristics of a 3-4PL-provider is almost impossible without the support of the state, including interaction with state agencies, including customs, organization of partnership with freight carrier organizations and other participants providing logistics processes.

In addition, the public administration should focus on solving problems that can only be done by them.

This is the development of a general programme for the development of logistics, taking into account a range of economic, transport, environmental, social and other factors, as well as methodological support, and it is necessary to improve and monitor the implementation of the rules and regulations of equipment and operation of terminal facilities, etc.

In addition, it is a profitable business for the state, whose macroeconomic effects are as follows:

- Reduction of the share of total national economic expenditures on the promotion of goods and goods in the GDP structure by $5-10 \%$;

- reducing the inflation rate by reducing logistics costs;

- increase of investment attractiveness of projects for placement of production facilities.

Improving the competitiveness of the economy through the creation of an effective modern logistics mechanism, which will provide at minimum cost to the economy:

- Integrated supply logistics for production centres;

- optimization of inventories and release of frozen financial resources;

- Integrated logistics for the distribution of goods from production centres to consumption centres (including imported goods).

The most important indirect effects will be:

- qualitatively improving the efficiency of consumer markets, increasing the availability of goods by reducing consumer prices, improving the quality and standard of living of the population;

- reduction of the cost of moving goods from production centers to consumers, reduction (phased "extinction") of non-productive intermediaries.

\section{REFERENCES}

1. 王凌峰 从国外经验看如何选择物流园区

electronic version: $h t t p: / / w w w . t r a d e t r e e . c n / c o n t e n t / 822 / 3 . h t m l$ from=singlemessage

2. 孙艳.“一带一路”战略环境下西安及西北区域物流发展策略研究[J].现代商业, 2017(24):46-49.

3. 刘志学,张宝洲,邹安全,付国庆.城市物流战略规划环境分析方法及其应用[J].系统工程, 2005(03):47-50.

4. 姜晶晶.宜昌保税物流中心的战略环境分析[J].现代经济信息, 2016(22):496.

5. 蔡远游. 港口物流园区规划战略环境评价指标体系研究 [D].厦门: 厦门大学,2007.

6. 余润东, 曾长虹. 衡阳市蒸湘区钢管物流园区发展战略环境分析 [J].中小企业管理与科技(下旬刊), 2011(03):210.

7. 鲁林.提供完善服务,推进“一带一路”物流商贸合作[J].大陆桥视野,2016(05):33-34.

8. 杨开林.两国三方打造中哈物流合作“升级版”[J].大陆桥视野,2017(05):20-21.

9. 杨柔坚.连云港:发挥“一带一路”战略中的独特优势[J].宏观经济管理,2014(11):83-84.

10. 沈坤荣.中国对外投资的现有格局与政策取向一一基于“一带一路”倡议的分析[A]. 全国高校社会主义经 济理论与实践研讨会领导小组.社会主义经济理论研究集萃（2017）：一一开启新时代的中国经济[C]. 全国高校社会主义经济理论与实践研讨会领导小组:中 国人民大学中国经济改革与发展研究院, 2017:16.

11. 刘开山.新视野、新引擎、新港城———带一路”战略与连云港东方节点城市建设 $[\mathrm{M}]$. 北京: 中国文 联出版社, 2017,1-2.

12. 刘汝丽.面向跨境电商的湖南省国际物流模式选择研究[D].长沙: 中南林业科技大学, 2018.

13. 蒋康莉 Study on Deepening the Construction of China-Kazakhstan (Lianyungang) Logistics Cooperation Base under the " B\&R" Initiative

14. Electronic resource: https://www.lobanov-logist.ru/library/all_articles/57650/\#

15. Electronic resource: https://news.myseldon.com/ru/news/index/197083525

16. Electronic resource: https://kapital.kz/economic/44060/port-lyan-yun-gan-uvelichit-gruzopotok-tovarovcherez-kazakhstan.html

17. Electronic resource: https://khabar.kz/ru/news/item/109672-kitajskij-port-lyanyungan-obrazets-mezhdunarodnogosotrudnichestva 